\title{
The effects of loggers on the foraging effort and chick-rearing ability of parent little auks
}

\author{
Dorota Kidawa $\cdot$ Dariusz Jakubas • \\ Katarzyna Wojczulanis-Jakubas • Lech Iliszko • \\ Lech Stempniewicz
}

Received: 8 July 2011/Revised: 15 November 2011/ Accepted: 18 November 2011/Published online: 2 December 2011

(C) The Author(s) 2011. This article is published with open access at Springerlink.com

\begin{abstract}
We studied the effects of loggers attached to chick-rearing little auks (Alle alle) on their daily time budget (proportion of time spent in the colony and at sea), foraging activity (duration and proportion of long and short foraging flights), chick provisioning rate and their growth and development on Spitsbergen. We found that experimental parent birds performed shorter but more frequent long foraging flights and reduced the frequency of short foraging flights. They spent more time at the colony and reduced chick provisioning rate compared to control birds. Nestlings reared by experimental parents weighed significantly less at their middle, peak and fledging age and departed colony later than chicks of control parents. Little auks depend on energy-rich copepods associated with cold Arctic waters and are expected to face the climate-induced worsening of the foraging conditions, which may have negative impact on their time/energy budget and survival. The study may help to determine the level of extra effort little auks need to invest to breed successfully.
\end{abstract}

Keywords Little auk - Alle alle $\cdot$ Logger .

Artificial burden $\cdot$ Foraging effort $\cdot$ Chick growth

\section{Introduction}

The breeding season is a period of high energy demands, as adults have to forage for themselves and also feed their offspring (Lack 1968). Long-lived species are limited in

D. Kidawa $(\bowtie) \cdot$ D. Jakubas $\cdot$ K. Wojczulanis-Jakubas .

L. Iliszko $\cdot$ L. Stempniewicz

Department of Vertebrate Ecology and Zoology, University

of Gdańsk, al. Legionów 9, 80-441 Gdańsk, Poland

e-mail: dorotakidawa@univ.gda.pl time and energy invested into current parental effort since overexertion may be detrimental to their future condition, survival and breeding opportunities (Stearns 1992; Saether et al. 1993; Paredes et al. 2005). Thus, seabirds breeding in suboptimal conditions are expected to respond to variations in food availability by adjusting their foraging behaviour (e.g. Hamer et al. 2007). Several authors suggest that stressed parents with experimentally increased flight costs prioritize self-maintenance over increased chick provisioning efforts when foraging costs become too high (Weimerskirch et al.1999; Velando and Alonso-Alvarez 2003; Harding et al. 2009c). On the other hand, there is some evidence that the other parent can fully or partially compensate for a reduction of the manipulated partner's parental effort by increasing its own investment above the usual levels (Paredes et al. 2005; Harding et al. 2009b, c).

The number of studies using data gathering devices attached to birds (e.g. time-depth recorders, radio transmitters, satellite transmitters) has increased considerably over recent years (e.g. Tremblay et al. 2003; Hamel et al. 2004; Iguan et al. 2005; Philips et al. 2003; Anker-Nilssen and Aarvak 2009). However, some studies indicate a potentially detrimental effect of devices on the birds' behaviour, possibly biasing the data collected (e.g. Sohle 2003; Paredes et al. 2005; Ropert-Coudert et al. 2007; Barron et al. 2010). The study of Saraux et al. (2011) demonstrated that even flipper banding in penguins has massive long-term negative impact on population growth rate. Several authors found that birds equipped with devices prolonged their foraging trips (Weimerskirch et al. 1999; Taylor and Leonard 2001) or reduced the quantity of food delivered to chicks (Tremblay et al. 2003; Ackerman et al. 2004; Paredes et al. 2005). Comparisons of foraging strategies of experimental and control individuals provide an opportunity to investigate reactions of individuals to 
increased costs of parental care and/or their partners' compensation. Such comparisons are still scarce.

Little auks (Alle alle) are small, planktivorous, longlived, colonial seabirds breeding in the high Arctic. They are considered the most abundant alcids in the Palaearctic (>37 million pairs; Stempniewicz 2001; Egevang et al. 2003). Hornsund and Magdalenefjorden are two main breeding areas of little auks in Svalbard (Isaksen 1995). Owing to the high cost of locomotion, both in the air (flapping flight) and in the water (wing-propelled diving), foraging in little auks is energetically expensive (Gabrielsen et al. 1991; Konarzewski et al. 1993; Stempniewicz 2001). As a consequence, they are forced to feed on energy-rich copepods associated with cold Arctic waters (Karnovsky et al. 2003; Wojczulanis et al. 2006; Jakubas et al. 2007, 2011a). Moreover, little auks use a dual foraging strategy consisting of several short and long trips (Steen et al. 2007; Welcker et al. 2009a; Wojczulanis-Jakubas et al. 2010). During energetically expensive short trips, parent birds appear to forage mainly for chick provisioning, while during the long trips, they feed and rest at the sea surface to restore their own energy reserves (Wojczulanis-Jakubas et al. 2010). The ranges of short trips were calculated to 12-33 km and long trips to $130-219 \mathrm{~km}$, based on the mean flight times of parent birds equipped with time-depth recorders (Welcker et al. 2009a). Data from GPS loggers confirm that little auks are able to forage on distant feeding grounds ( $>100 \mathrm{~km}$ away from the colony) (Jakubas et al. 2011b).

Breeding season in little auks starts between late February and early May and is strongly determined by snow melting in spring, which allows birds to enter the nest (Stempniewicz 2001; Moe et al. 2009; Jakubas and Wojczulanis-Jakubas 2011). Little auks lay a single egg in late June. Nests are concealed under the surface in extensive boulder screes (talus). Egg is incubated by both parents for 28-29 days. Biparental care is also provided to the chicks that are brooded until they become homeothermic (3-4 days) and fed until they leave the colony (Stempniewicz 1981, 2001; Harding et al. 2004). Energy demands of little auk chicks ( $262 \mathrm{~kJ}$ per day; Konarzewski et al. 1993) are much higher than those of other seabird chicks of similar body mass. Also, their maximum growth rates (g/day; expressed as a percentage of adult mass) are more than twice those of other Alcidae. Chicks reach their peak body mass $(120-124 \mathrm{~g}$, max $150 \mathrm{~g})$ at the age of 19-24 days, and fledge weighing 110-114 g on average (Stempniewicz 1980, 2001). Body mass recession preceding fledging may be associated with a reduction in feeding frequency (females cessate feeding before fledging, probably due to a sex-specific role in parental care during and after fledging and/or an ancestral pattern of parental care; Wojczulanis-Jakubas et al. 2011), tissue maturation and/or might be an essential prerequisite for efficient flight
(Ricklefts 1968; Gaston 1985; Taylor and Konarzewski 1989; Stempniewicz 1980, 2001). The fledging age of chicks varies among individuals. Most chicks leave the colony at 25-27 days of age, but chicks as young as 20 days old have been observed as well (Stempniewicz 2001; Harding et al. 2004).

The aim of this study was to test the hypothesis that little auk parents carrying an extra load (logger) of small weight (0.9-3.4\% of body mass) have undisturbed chick provisioning, chick development and survival rates. We compared number of chick feeds, duration of foraging flights, proportions of long and short foraging trips, time spent in the colony by experimental and control parent birds, chick body mass at mid, peak and fledging stages, and breeding success between the experimental and control nests.

In earlier studies on artificially burdened little auks, Harding et al. (2009b, c) examined changes in condition (body mass and plasma corticosterone level) of parents with clipped primaries and their chicks, Welcker et al. (2009a) and Karnovsky et al. (2011) used temperature recording loggers to study the foraging behaviour.

This is the first study describing simultaneously the effects of artificially increased flight costs of parent little auks equipped with loggers on their time budget, foraging activities, as well as on chick provisioning, growth rate and survival during the nesting period.

\section{Materials and methods}

The study was carried out in two breeding colonies of little auks in Spitsbergen, Alkekongen in Magdalenefjorden $\left(79^{\circ} 35^{\prime} \mathrm{N}, 1^{\circ} 05^{\prime} \mathrm{E}\right)$ and Ariekammen in Hornsund $\left(77^{\circ} 00^{\prime} \mathrm{N}, 15^{\circ} 22^{\prime} \mathrm{E}\right)$ during the chick-rearing periods in July-August 2009 and 2010. To determine the effects of data loggers on parental behaviour and chick growth, we compared experimental (E, one parent loaded with logger) and control nests (C, both parents without logger; Table 1).

Two types of loggers were used: temperature loggers (ECOTONE ETL 1, Ecotone, Sopot, Poland) and global positioning system (GPS) loggers (ECOTONE PATRON EP-2, Ecotone, Sopot, Poland). One bird would carry only one logger.

The temperature loggers were oval, measured $14 \times$ $15 \times 4 \mathrm{~mm}$ and weighed $1.0 \mathrm{~g}$. Birds were caught in the nests during the early chick-rearing period, and loggers were attached to the belly feathers using LOCTITE 4860 cyanoacrylate glue (Henkel Corp., Rocky Hill, Connecticut, USA) at approximately the midpoint of the centre-line of the body. The logger together with the potting mass $(1.5 \mathrm{~g})$ was equivalent to $0.9 \%$ of an average birds' body mass (mean body mass of the adults measured during the early chick-rearing period: $166.2 \pm 11.60 \mathrm{~g}, n=52$ ) and 
Table 1 Study area and season, number and type of loggers, number of experimental and control birds studied

\begin{tabular}{ccccc}
\hline Colony and Season & Loggers attached to adult birds & Measure & Experimental group & Control group \\
\hline Hornsund 2009 & $\begin{array}{c}\text { 10 temperature loggers } \\
\text { 5 GPS loggers }\end{array}$ & Chick body mass & 15 chicks & 58 chicks \\
\hline Magdalenefjorden 2009 & 9 temperature loggers & Chick body mass & 9 chicks & 70 chicks \\
\cline { 2 - 4 } Magdalenefjorden 2010 & 10 GPS loggers & Foraging effort & 8 adult birds & 11 adult birds \\
\hline
\end{tabular}

constituted $1.5 \%$ of birds' frontal area (cross-sectional area). Birds were released back into the nest after $10 \mathrm{~min}$ of handling. Regular checks at the nests started $24 \mathrm{~h}$ after attachment and were continued until the birds were recaptured and the loggers removed.

The GPS loggers $(40 \times 17 \times 9 \mathrm{~mm})$ were attached to bird's central back feathers with 10-mm-wide Tesa tape (code 4965; Tesa Tape Inc., Charlotte, North Carolina, USA). Birds were caught in the nests during the chickrearing period and were released back into the nest after no more than 25 min of handling. The logger mass (including attachment $=5.4-5.7 \mathrm{~g}$ ) was equivalent to $3.2-3.4 \%$ of an average little auk's body mass and constituted $3.9 \%$ of birds' frontal area. The nests were checked every day, starting from $24 \mathrm{~h}$ after the birds handling and continued until their recapture.

All birds, those carrying the loggers (experimental) and control birds, were handled in a similar manner (control birds handling time-10 min) and were marked individually with temporary colour marks dyed on their breasts (control birds were additionally marked with combinations of plastic colour rings) for quick identification during observation. This double marking system allowed to recognize the birds correctly and quickly.

Temperature and GPS records from the same experimental birds were used to study their foraging ecology and published separately (Jakubas et al. 2011b). In the current paper, we focus on the influence of both types of loggers carried by parent birds on chick growth and development, while changes in foraging performance of parent birds were investigated only in birds loaded with temperature loggers.

\section{Foraging effort}

Both experimental $(N=9)$ and control nests $(N=70)$ were randomly chosen throughout the colony in Magdalenefjorden in 2009. The number of chick feeds, duration of foraging trips and time spent in the colony per $24 \mathrm{~h}$ were compared between experimental and control parent birds with chicks of similar age (1-8 days old). Thus, 8 experimental and 11 control birds were compared (Table 1).
In total, we obtained $1,930 \mathrm{~h}$ of temperature records from the 8 individuals. On the basis of the recorded temperature distribution, three main types of little auk activity were distinguished: presence in the colony, flight and presence on the water (Tremblay et al. 2003; Welcker et al. 2009a; Jakubas et al. 2011b). The period of high temperatures was considered to be a presence in the colony. Decrease in temperature recorded after that period was interpreted as departure from the colony. A further steep decrease in temperature was considered as landing on the water and presence on the sea surface. Subsequent rapid increase in temperature was interpreted as take-off from the water and flight (see Jakubas et al. 2011b for more details). The frequency distribution of foraging trip durations was bimodal, shown as two separate log-normal distributions of short and long trips (see later). The difference between the means of the distributions was greater than the sum of their standard deviations (Schilling et al. 2002). The cut-off value separating short and long trips $(6 \mathrm{~h}$ for experimental and $10 \mathrm{~h}$ for control birds) was obtained by calculating the minimal sum of the variances of both trip types given their log-normal distribution (Welcker et al. 2009a).

In the control group, we carried out one continuous $48 \mathrm{~h}$ observation of 11 parent birds from nests situated in close proximity, thus allowing observers to watch all marked birds. Little auks transport food for their chicks in the gular pouch. When they arrive in colony from the sea, they sit in the vicinity of the nest for a while, resting and socializing, both before entering and/or after exiting the nest. The presence or absence on the surface of the colony and all departures and arrivals with/without food of the marked individuals were noted. Under continuous daylight conditions, the visibility of birds was comparable throughout the whole period of observation.

\section{Chick body mass}

Growth of chicks from experimental (both logger types combined) and control nests was investigated during two seasons in two breeding colonies (Table 1). In order to estimate the chick hatching dates, the nests were checked every 2 days. Loggers were attached to parent birds when 
their chicks were less than 14 days old. Chicks from both groups were weighed with an electronic balance (OHAUS, accurate to $0.1 \mathrm{~g}$ ) every 3 days starting from the 14th day of their life, when chicks began to exercise their wings outside the nest chamber. Measurements continued until the chicks left the colony.

Body mass of the chicks at three stages of their life was compared between the experimental and control groups. Chicks were measured at the age of 14-15 days, when they achieved peak mass (the highest mass measured), and prior to fledging (measured before colony departure). Since the growth-curve measure is not influenced by the particular asymptote that individual chicks attain (Gaston 1985), the peak and fledging mass are considered to be effective growth indicators (Zach 1988; Jakubas and WojczulanisJakubas 2011).

The analyses of fledging body mass do not contain data from Hornsund, since studies at that site had finished before the chicks fledged. Chick survival was estimated as the percentage of nests from which chicks disappeared after 20 days of age (when they were assumed to have fledged) (Harding et al. 2004; Welcker et al. 2009a).

All data were tested for normality and homogeneity of variances, and the parametric assumptions were not met. Therefore, non-parametric tests were used to compare experimental and control parents and their chicks (MannWhitney $U$ tests, Kruskal-Wallis and Dunn's tests). All analyses were conducted using Statistica 9.0.

\section{Results}

Foraging effort

The frequency of chick feds by a parent birds per $24 \mathrm{~h}$ was significantly lower in the experimental parents (median $=2, \mathrm{Q}_{1}-\mathrm{Q}_{3}=1.5-3, N=32$ ) compared to the control birds (median $=4, \mathrm{Q}_{1}-\mathrm{Q}_{3}=2-5, N=23$; Mann-Whitney $U$ test, $Z=3.02, P=0.002$; Fig. 1 ).

The durations of foraging trips performed by experimental birds were significantly longer (median $=271.6$ min, $\left.\mathrm{Q}_{1}-\mathrm{Q}_{3}: 134-638 \mathrm{~min}, N=66\right)$ than in the control group (median $=140 \mathrm{~min}, \mathrm{Q}_{1}-\mathrm{Q}_{3}: 100-269 \mathrm{~min}, N=73$; Mann-Whitney $U$ test, $Z=2.72, P=0.007$; Fig. 2).

The temperature logger data and observation of control individuals indicated that during the early chick-rearing period, little auks from Magdalenefjorden adopted a bimodal foraging trip strategy, alternating one long trip with several short foraging trips (Fig. 3). The duration of the long foraging trips was significantly longer in control birds (median $=850 \mathrm{~min} ; \mathrm{Q}_{1}-\mathrm{Q}_{3}: 760-959 \mathrm{~min}, N=10$ ), compared to experimental birds (median $=659 \mathrm{~min}$; $\mathrm{Q}_{1}-\mathrm{Q}_{3}: 558-788 \mathrm{~min}, \quad N=29$; Mann-Whitney $U$ test,

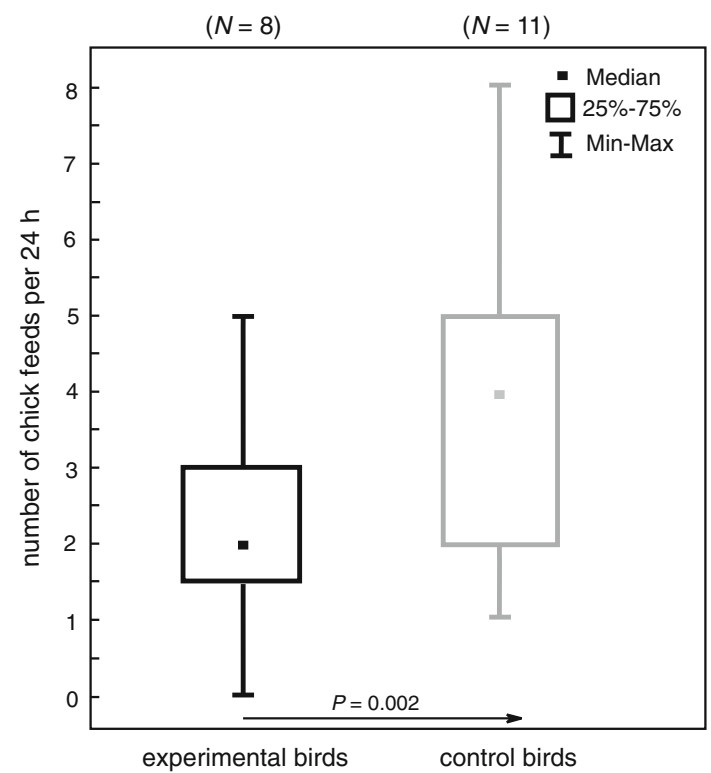

Fig. 1 Number of chick feeds per $24 \mathrm{~h}$ performed by experimental and control parent little auks studied in Magdalenefjorden colony in 2009. Sample sizes are provided in parentheses. Significant differences are indicated by arrows (Mann-Whitney $U$ test, $P<0.05$; see text for details)

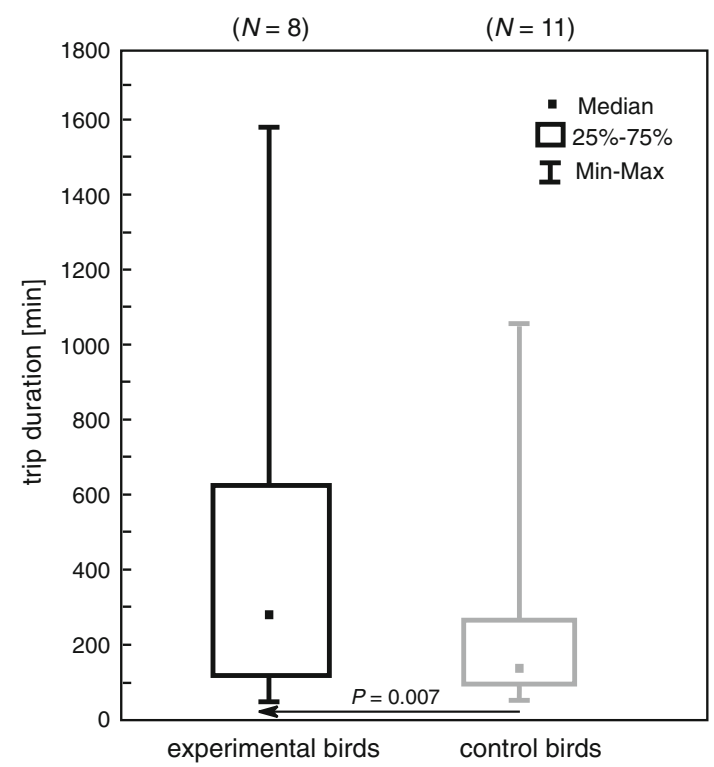

Fig. 2 Foraging trip duration in experimental and control parent little auks studied in Magdalenefjorden colony in 2009. Sample sizes are provided in parentheses. Significant differences between chicks are indicated by arrows (Mann-Whitney $U$ test, $P<0.05$; see text for details)

$Z=2.27, P=0.023)$, while the duration of the short foraging trips was similar in the experimental (median $\left.=138 \mathrm{~min}, \mathrm{Q}_{1}-\mathrm{Q}_{3}: 80-236 \mathrm{~min}, N=37\right)$ and control birds $\left(\right.$ median $=131 \mathrm{~min}, \mathrm{Q}_{1}-\mathrm{Q}_{3}: 91-196 \mathrm{~min}, N=63$; Mann-Whitney $U$ test, $Z=0.09, P=0.93$ ). Moreover, the frequency distribution of the foraging trips duration 
Fig. 3 Relative frequency distribution of foraging flights performed by experimental ( $n=8$ birds; 66 flights) and control parent little auks ( $n=11$ birds; 73 flights) in Magdalenefjorden colony in 2009

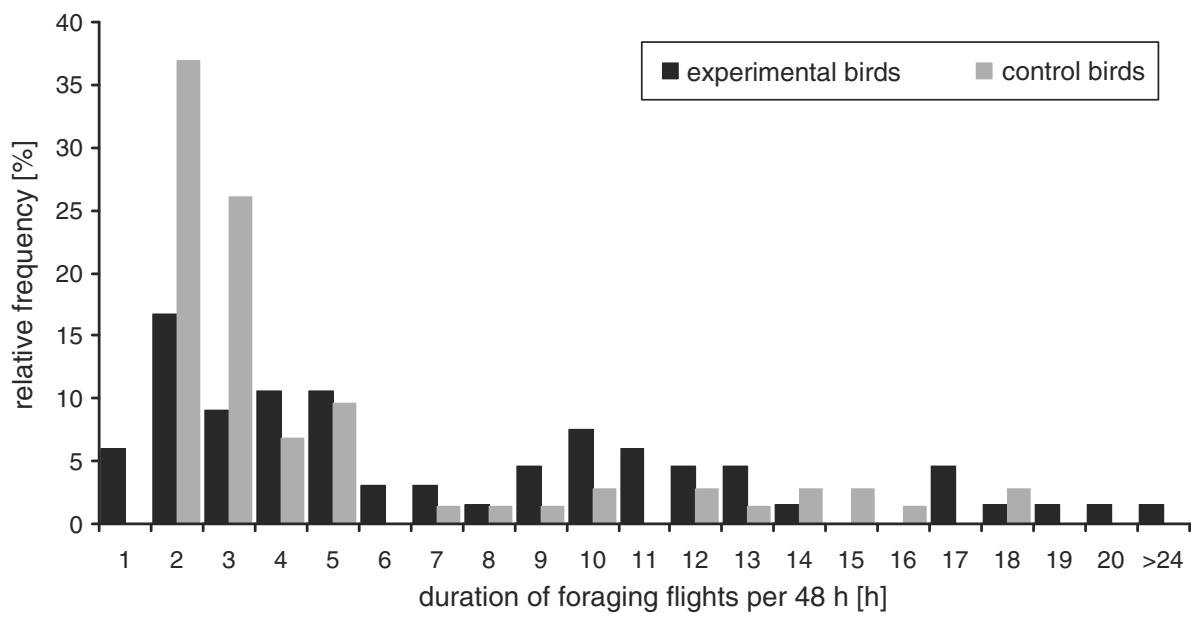

differed between the groups (Kolmogorow-Smirnow test, $D=0.048, P=0.02, N=21$; Fig. 3 ). The ratio of short versus long trips differed between the control and experimental birds $\left(\chi^{2}\right.$ test, $\left.\chi^{2}=14.24, P=0.0002\right)$, with a lower frequency of short trips in the experimental $(56 \%)$ than control birds (86\%).

The overall time experimental birds spent in the colony per $24 \mathrm{~h}$ were significantly longer (median $=531 \mathrm{~min}$, $\mathrm{Q}_{1}-\mathrm{Q}_{3}: 398-494, N=32$ ) than the control birds (median $=217 \mathrm{~min}, \mathrm{Q}_{1}-\mathrm{Q}_{3}: 179-358 \mathrm{~min}, N=11$; MannWhitney $U$ test, $Z=3.71, P=0.0002$; Fig. 4).

Chick body mass

None of the chick body mass parameters differed between the two types of loggers used (temperature loggers vs. GPS

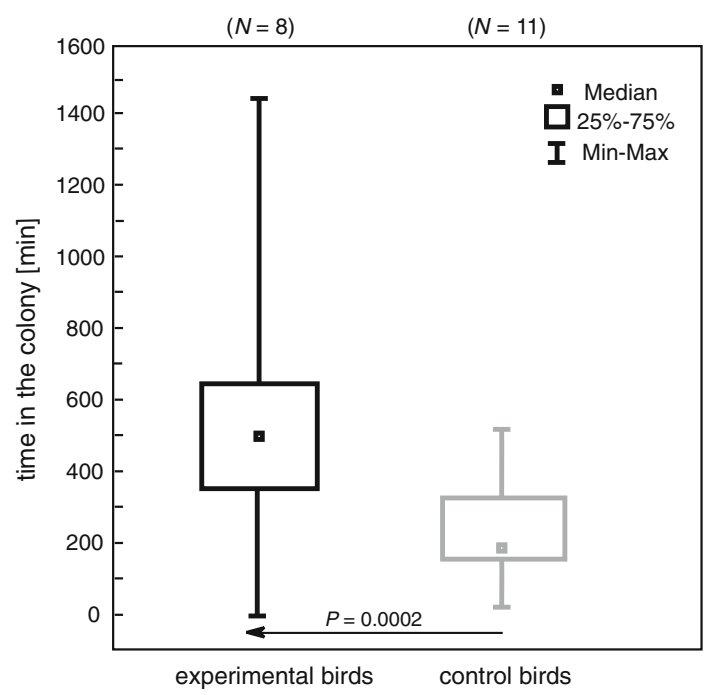

Fig. 4 Time spent in colony by experimental and control parent little auks studied in Magdalenefjorden colony in 2009. Sample sizes are provided in parentheses. Significant differences between chicks are indicated by arrows (Mann-Whitney $U$ test, $P<0.05$; see text for details) loggers, see Table 1; Mann-Whitney test: $0.05<P<$ 0.68). No significant differences were also found in the studied chick body mass parameters between the two colonies and years of study (Hornsund 2009 vs. Magdalenefjorden 2009 vs. Magdalenefjorden 2010, see Table 1; Kruskal-Wallis and Dunn's tests: $0.18<P<0.87$ ). Considering this lack of differences for the device types, colonies and years, data of chicks' body mass were pooled to increase sample size.

At the age of 14-15 days, chicks from the experimental nests had a significantly lower body mass (median $=87 \mathrm{~g}$, $\left.\mathrm{Q}_{1}-\mathrm{Q}_{3}: 68-97 \mathrm{~g}, N=23\right)$ than chicks from the control group $\left(\right.$ median $=109.5 \mathrm{~g}, \mathrm{Q}_{1}-\mathrm{Q}_{3}: 102-117 \mathrm{~g}, N=127$; Mann-Whitney $U$ test, $Z=-5.63, P<0.001$; Fig. 5). Chicks from both groups reached their peak body mass at a similar age (14-28 and 13-25 days, respectively). However, chicks from the control nests achieved significantly higher peak body mass $\left(\right.$ median $=123.8 \mathrm{~g}, \mathrm{Q}_{1}-\mathrm{Q}_{3}$ : $118-131 \mathrm{~g}, N=113)$ compared to experimental chicks $\left(\right.$ median $=101.6 \mathrm{~g}, \mathrm{Q}_{1}-\mathrm{Q}_{3}: 84-117 \mathrm{~g}, N=31$; MannWhitney $U$ test, $Z=-5.94, P<0.001$; Fig. 5).

Furthermore, experimental chicks fledged 3 days later than control chicks (Mann-Whitney $U$ test, $Z=3.37$, $P<0.001$; Fig. 6). Fledging body mass of nestlings from experimental nests $\left(\right.$ median $=81.7 \mathrm{~g}, \mathrm{Q}_{1}-\mathrm{Q}_{3}: 74-109 \mathrm{~g}$, $N=13$ ) was also significantly lower compared to the control ones (median $=111.8 \mathrm{~g}, \mathrm{Q}_{1}-\mathrm{Q}_{3}: 107-117 \mathrm{~g}, N=44$; Mann-Whitney $U$ test, $Z=-3.80, P<0.001$; Fig. 5).

Chick mortality/survival during the nesting period was not affected by the artificial extra loading of the parent birds (Table 2).

\section{Discussion}

Experimental birds reduced the number of food deliveries, spent more time at the colony and less time at the sea 


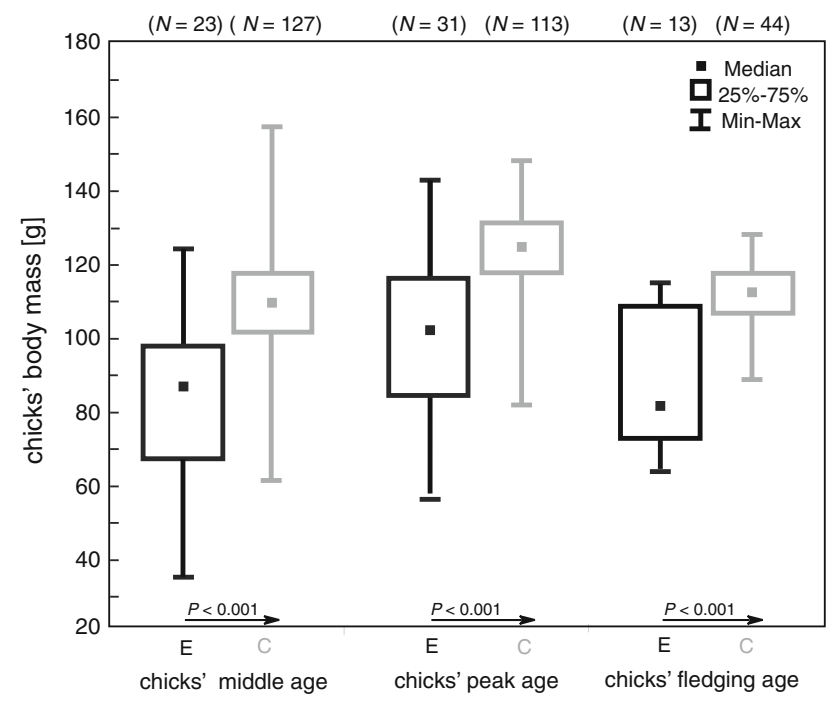

Fig. 5 Middle (14-15 day of life), peak and fledging body mass of chicks reared by experimental (E, black frames) and control (C, grey frames) parent little auks. Sample sizes are provided in parentheses. Significant differences between chicks' body masses are indicated by arrows (Mann-Whitney $U, P<0.05$; see text for details)

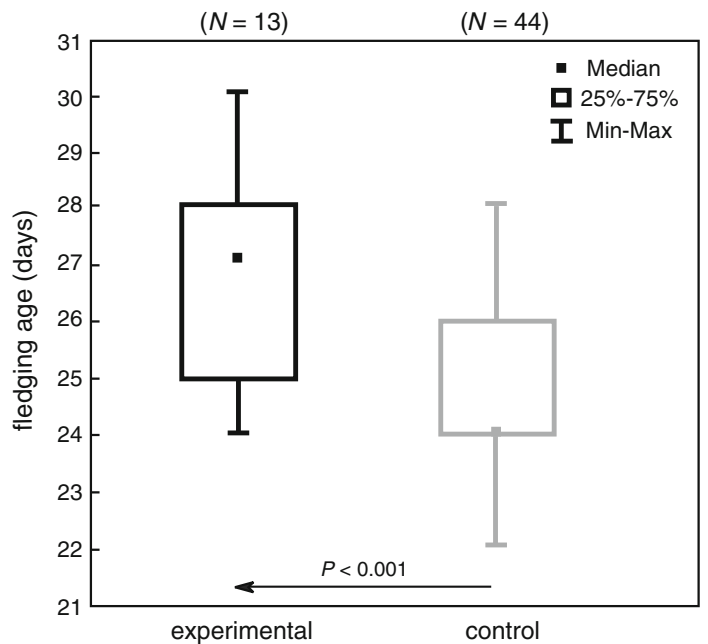

Fig. 6 Fledging age of chicks reared by experimental and control parent little auks. Sample sizes are provided in parentheses. Significant differences between chicks are indicated by arrows (and Dunn's tests, $P<0.05$; see text for details)

compared to the control birds. Moreover, foraging trip durations were generally longer, but trips were less frequent in the experimental group compared to the control birds. Both experimental and control birds adopted a bimodal foraging strategy, although experimental individuals performed long foraging trips (hypothesized as selffeeding trips) more frequently, and short foraging trips (presumably for chick provisioning) less frequently than control birds.

These findings along with the results of the previous studies (Weimerskirch et al. 1999; Taylor and Leonard 2001; Sohle 2003; Tremblay et al. 2003; Ackerman et al. 2004; Paredes et al. 2005; Ropert-Coudert et al. 2007; Barron et al. 2010) strongly suggest that logger attachments might impact the energetics and behaviour of parent birds. Indeed, results of our study revealed that reduced provisioning of the experimental little auk parents had detrimental effects on the chicks growth. The body mass of 14-day-old chicks, as well as their peak and fledging body mass, were significantly lower than in the control group. On the other hand, chick survival was not affected by reduced provisioning of the experimental parents. Several papers have documented that the fledging body mass is not always related to the subsequent survival in alcids (Hedgren 1981; Harris et al. 1992). For example, the probability of survival in ancient murrelets Synthliboramphus antiquus increased in chicks with higher departure mass. However, in precocial, chicks are never fed in the nest and depart the nest to sea within the first 3 days after hatching (Gaston 1997).

Despite the fact that loggers did not restrain parent birds from reaching remote foraging areas (Jakubas et al. 2011b), some aspects of their behaviour, feeding frequency, and consequently, chick growth were impaired.

The weight and size of a device may be of crucial significance. According to previous studies (Caccamise and Hedin 1985; Calvo and Furness 1992; Wilson and Culik 1992), the mass of the fixed device should not exceed 5\% of the bird body mass, while Kenward (1987) suggests that even devices constituting 3\% might have a negative impact on birds' flight agility. According to Paredes et al. (2005) and Harding et al. (2009a), data loggers weighing approximately $3.0-3.3 \%$ of the bird body mass negatively affected the diving depth and duration, provisioning rates and frequency of foraging trips. Even small devices equivalent to $<0.5 \%$ of the common guillemots Uria aalge body mass (Tremblay et al. 2003) and $<2 \%$ in case of the little auks (Welcker et al. 2009a) appeared to have negative

Table 2 Chick survival in experimental (E) and control (C) parent little auks

\begin{tabular}{cccccccccc}
\hline & \multicolumn{2}{c}{ Hornsund 2009 } & \multicolumn{2}{c}{ Magdalenefjorden 2009 } & \multicolumn{2}{c}{ Magdalenefjorden 2010 } & \multicolumn{2}{c}{ Overall } & \multicolumn{2}{c}{ Fisher exact test } \\
& E & C & E & C & E & C & E & C & for overall \\
\hline Chick survival & $100 \%(13)$ & $98.2 \%(56)$ & $100 \%(9)$ & $98.6 \%(70)$ & $100 \%(10)$ & $97.6 \%(42)$ & $100 \%(32)$ & $98.2 \%(168)$ & $P=1.0000$ \\
\hline
\end{tabular}

Number of studied chicks in parentheses 
effects on the frequency and length of foraging trips performed by burdened birds.

Wilson et al. (1986) claimed that non-breeding African penguins Spheniscus demersus with devices up to a maximum of $6.8 \%$ in frontal area could still balance their energy budgets. However, an experiment with little penguins Eudyptula minor equipped with two types of loggers showed that large devices considerably modified the diving behaviour (Ropert-Coudert et al. 2007). Birds with smaller loggers (3.4\% vs. $4.9 \%$ of the bird's frontal area) dived deeper and were more efficient in capturing prey, while the effects of the different logger positions (back and middle of the penguin's back) appeared negligible (Ropert-Coudert et al. 2007). Also, studies on thick-billed murres Uria lomvia revealed that the drag produced by data loggers, which constituted $1.2-1.3 \%$ of the birds' frontal area, affected the underwater swimming performance and increased the energy costs (Paredes et at. 2005). Karnovsky et al. (2011) ensured that the effect of loggers, which constituted $\sim 2 \%$ of the cross-sectional area and $1.6 \%$ of the average bird's body mass, was negligible. However, time allocation of experimental birds was not compared with the control group, birds equipped with loggers lost $3.1 \%$ of the average initial mass and only 6 of the 11 experimental birds in one of the study areas were observed feeding chicks during and after the logger attachment.

Drag is the main mechanical cost to diving birds (Lovvorn et al. 2001), but a part of the extra expenditure could be due to exertion to retain balance rather than to drag (Culik et al. 1994). In the current study, the direct effect of two loggers, varying in size, weight and place of attachment (larger, back-mounted and smaller, bellymounted) on birds' foraging behaviour could not be compared. However, there were no significant differences in the experimental chicks' growth, what may suggest that the total effect of two types of loggers was similar. Considering that in flying birds devices should be placed between the shoulder blades to be optimally balanced (Obrecht et al.1988), it is likely that more favourable position of the back-mounted loggers compensated for their larger size and weight. However, the synthetic study of Barron et al. (2010) shows that the effects of devices do not vary with the method of attachment for most aspects of avian behaviour and ecology. Moreover, Godfrey and Bryant (2003) in the review study suggest that the different severity of stress-related effects of devices in birds and mammals may be more important than locomotion medium itself, as land-based animals were more likely to show a deleterious impact of devices.

Although long-living seabirds are not expected to increase their breeding investment in response to a reduction in parental care by the partner (Beaulieu et al. 2009), Harding et al. (2009c) suggested that little auks have the capacity to increase the provision rate in response to reduced efforts of the mate. A possible explanation of this compensatory behaviour is an increased chick begging behaviour in response to increased corticosterone secretion (Kitayski et al. 2001). However, the lower body mass of the experimental chicks found in the present study, as well as shown in the study by Harding et al. (2009c), indicate that in little auks, a reduced food delivery rate by one partner is not fully compensated for by the other.

Our results offer an opportunity to test the chicks' endurance to a declined feeding rate. Even when the number of feeds per chick per $24 \mathrm{~h}$ is reduced by $25 \%$, that is, from 8 (median in control group $\times 2$ parents) to 6 times (median in experimental birds + median in control birdspartner), chicks were still able to fledge, though at the cost of lower fledging body mass and longer nesting phase. This knowledge may be crucial for constructing reliable scenarios of climate-induced changes in zooplankton composition and availability in the little auk feeding grounds. Predicted shift towards a warmer climate scenario is likely to favour smaller boreal zooplankton species, with a lower energy content compared to the copepods little auks are currently feeding on (Falk-Petersen et al. 2007; Stempniewicz et al. 2007). This may have a negative impact on the little auks' time and energy budgets, feeding frequency, breeding success and range of distribution (Kwasniewski et al. 2010; Jakubas et al. 2011a). Based on sea surface temperature modelling, Karnovsky et al. (2010) predict that many little auk colonies in the Nordic Seas will face a shift towards a zooplankton community dominated by small Calanus finmarchicus by the end of the twenty-first century. In Iceland, in the first half of last century, little auks abandoned their colonies following a shift in sea currents and plankton dispersal (Nettleship and Evans 1985). Quite extreme predictions indicate that a strong reduction in sea ice coverage in future years might induce the breeding failure of the whole Spitsbergen population (Joiris and Falck 2010). Little auks exploiting less favourable foraging grounds may increase their foraging effort to a certain extent (Jakubas et al. 2007; Kwasniewski et al. 2010; Jakubas et al. 2011a). However, those extra costs may have detrimental effects in the subsequent breeding season, appearing in the reduction of future survival and/or breeding attempt (Welcker et al. 2009b). It is likely that in worsening foraging conditions (like in Iceland), stressed adults may reach a threshold of prioritizing self-maintenance over increased provisioning effort when foraging costs become too high.

Acknowledgments We would like to thank Liliana Keslinka, Jan Samołyk, Gosia Jakimiak and Wojtek Iliszko for their help in the field work. We thank Zdzisław Błoński for creating application for visual inspection of temperature curves. Study was supported by grants from Polish Ministry of Science and Higher Education (1883/P01/2007/32, 
IPY/25/2007) Norwegian Financial Mechanism (ALKEKONGE, PNRF-234-AI-1/07) and University of Gdańsk (538-L120-0781-1). The study was conducted under the permission of the Governor of Svalbard and the Norwegian Animal Research Authority.

Open Access This article is distributed under the terms of the Creative Commons Attribution Noncommercial License which permits any noncommercial use, distribution, and reproduction in any medium, provided the original author(s) and source are credited.

\section{References}

Ackerman JT, Adams J, Takekawa JY, Carter HR, Whitworth DL, Newman SH, Golightly RT, Orthmeyer DL (2004) Effects of radio transmitters on the reproductive performance of Cassin's auklets. Wildlife Soc Bull 32:1229-1241. doi:10.2193/00917648(2004)032[1229:EOROTR]2.0.CO;2

Anker-Nilssen T, Aarvak T (2009) Satellite telemetry reveals postbreeding movements of Atlantic puffins Fratercula arctica from Røst, North Norway. Polar Biol 32:1657-1664. doi:10.1007/ s00300-009-0665-7

Barron DG, Brawn JD, Weatherhead PJ (2010) Meta-analysis of transmitter effects on avian behaviour and ecology. Methods Ecol Evol 1:180-187. doi:10.1111/j.2041-210X.2010.00013.x

Beaulieu M, Raclota T, Dervauxa A, Le Mahoa Y, Ropert-Coudert Y, Ancela A (2009) Can a handicapped parent rely on its partner? An experimental study within Adelie penguin pairs. Anim Behav 78:313-320. doi:10.1016/j.anbehav.2009.05.006

Caccamise DF, Hedin RS (1985) An aerodynamic basis for selecting transmitter loads in birds. Wilson Bull 97:306-318

Calvo B, Furness RW (1992) A review of the use and the effects of marks and devices on birds. Ring Migr 13:29-151

Culik BM, Bannasch R, Wilson RP (1994) External devices on penguins: how important is shape? Mar Biol 118:353-357

Egevang C, Boertmann D, Mosbech A, Tamstorf MP (2003) Estimating colony area and population size of Little Auks Alle alle, at Northumberland Island using aerial images. Polar Biol 26:8-13. doi:10.1007/s00300-002-0448-x

Falk-Petersen S, Pavlov V, Timofeev S, Sargent JR (2007) Climate variability and possible effects on arctic food chains: the role of Calanus. Arct Alp Ecosyst People Chang Environ Part 2:147-166. doi:10.1007/978-3-540-48514-8_9

Gabrielsen GW, Taylor JRE, Konarzewski M, Mehlum F (1991) Field and laboratory metabolism and thermoregulation in dovekies (Alle alle). Auk 108:71-78

Gaston AJ (1985) Development of the young in the Atlantic Alcidae. In: Birkhead TR, Nettleship DN (eds) The Atlantic Alcidae. Academic Press, London, pp 319-354

Gaston AJ (1997) Mass and date at departure affect the survival of Ancient Murrelet Synthliboramphus antiquus chicks after leaving the colony. Ibis 139:673-678

Godfrey JD, Bryant DM (2003) Effects of radio transmitters: Review of recent radio-tracking studies. In: Williams M (Comp.) 2003: Conservation applications of measuring energy expenditure of New Zealand birds: assessing habitat quality and costs of carrying radio transmitters Science for Conservation 214, pp 83-95

Hamel NJ, Parrish JK, Conquest LL (2004) Effects of tagging on behaviour, provisioning, and reproduction in the common murre (Uria aalge), a diving seabird. Auk 121:1161-1171. doi: 10.1642/00048038(2004)121[1161:EOTOBP]2.0.CO;2

Hamer KC, Humphreys EM, Garthe S, Hennicke J, Peters G, Gremillet D, Phillips RA, Harris MP, Wanless S (2007) Annual variation in diets, feeding locations and foraging behaviour of gannets in the North Sea: flexibility, consistency and constraint. Mar Ecol Prog Ser 338:295-305

Harding AMA, Van Pelt TI, Lifjeld JT, Mehlum F (2004) Sex differences in Little Auk Alle alle parental care: transition from biparental to paternal-only care. Ibis 146:642-651. doi:10.1111/ j.1474-919X.2004.00297.x

Harding AMA, Egevang C, Walkusz W, Merkel F, Blanc S, Gremillet D (2009a) Estimating prey capture rates of a planktivorous seabird, the little auk (Alle alle), using diet, diving behaviour, and energy consumption. Polar Biol 32:785-796. doi: 10.1007/s00300-009-0581-x

Harding AMA, Kitaysky AS, Hamer KC, Hall ME, Welcker J, Talbot SL, Karnovsky NJ, Gabrielsen GW, Gremillet D (2009b) Impacts of experimentally increased foraging effort on the family: offspring sex matters. Anim Behav 78:321-328

Harding AMA, Kitaysky AS, Hall ME, Welcker J, Karnovsky NJ, Talbot SL, Hamer KC, Gremillet D (2009c) Flexibility in the parental effort of an Arctic-breeding Seabird. Func Ecol 23: 348-358. doi:10.1111/j.1365-2435.2008.01488.x

Harris MP, Halley DJ, Wanless S (1992) The post-fledging survival of young guille-mots Uria aalge in relation to hatching date and growth. Ibis 134:335-339

Hedgren S (1981) Effects of fledging weight and timing of fledging on survival of guillemot Uria aalge chicks. Ornis Scand 12:51-54. doi: $10.2307 / 3675904$

Iguan JM, Forero MG, Tavecchia G, Gonzalez-Solis J, MartinezAbrain A, Hobson KA, Ruiz X, Oro D (2005) Short-term effects of data-loggers on Cory's shearwater (Calonectris diomedea). Mar Biol 146:619-624. doi:10.1007/s00227-004-1461-0

Isaksen K (1995) The breeding population of little auk (Alle alle) in colonies in Hornsund and northwestern Spitsbergen. In: Isaksen $\mathrm{K}$, Bakken V (eds) Seabird populations in the northern Barents Sea. Nor Polarinst Medd 135:49-57

Jakubas D, Wojczulanis-Jakubas K (2011) Subcolony variation in phenology and breeding parameters in little auk Alle alle. Polar Biol 34:31-39. doi:10.1007/s00300-010-0856-2

Jakubas D, Wojczulanis-Jakubas K, Walkusz W (2007) Response of dovekie to changes in food availability. Waterbirds 30:421-428. doi:10.1675/1524-4695(2007)030[0421:RODTCI]2.0.CO;2

Jakubas D, Głuchowska M, Wojczulanis-Jakubas K, Karnovsky NJ, Keslinka L, Kidawa D, Walkusz W, Boehnke R, Cisek M, Kwaśniewski S, Stempniewicz L (2011a) Different foraging effort does not influence body condition and stress level in little auks. Mar Ecol Prog Ser 432:277-290. doi:10.3354/meps09082

Jakubas D, Iliszko L, Wojczulanis-Jakubas K, Stempniewicz L (2011b) Foraging by little auks in the distant marginal sea ice zone during the chick-1 rearing period. Polar Biol. (in press). doi:10.1007/s00300-011-1034-x

Joiris CR, Falck E (2010) Summer at-sea distribution of little auks Alle alle and harp seals Pagophilus (Phoca) groenlandica in the Fram Strait and the Greenland Sea: impact of small-scale hydrological events. Polar Biol 34:541-548. doi:10.1007/ s00300-010-0910-0

Karnovsky NJ, Kwaśniewski S, Węsławski JM, Walkusz W, Beszczyńska-Möller A (2003) The foraging behaviour of little auks in a heterogenous environment. Mar Ecol Prog Ser 253:289-303. doi:10.3354/meps253289

Karnovsky NJ, Harding A, Walkusz W, Kwasniewski S, Goszczko I, Wiktor J Jr, Routti H, Bailey A, McFadden L, Brown Z, Beaugrand G, Grémillet D (2010) Foraging distributions of little auks Alle alle across the Greenland Sea: implications of present and future Arctic climate change. Mar Ecol Prog Ser 415:283-293. doi:10.3354/meps08749

Karnovsky NJ, Brown ZW, Welcker J, Harding AMA et al (2011) Inter-colony comparison of diving behavior of an Arctic top 
predator: implications for warming in the Greenland Sea. Mar Ecol Prog Ser 440:229-240. doi:10.3354/meps09351

Kenward R (1987) Wildlife radio tagging, equipment, field techniques and data analysis. Academic Press, London

Kitaysky AS, Wingfield JC, Piatt JF (2001) Corticosterone facilitates begging and affects resource allocation in the black-legged kittiwake. Behav Ecol 12:619-625. doi:10.1093/beheco/12.5.619

Konarzewski M, Taylor JRE, Gabrielsen GW (1993) Chick energy requirements and adult energy expenditures of dovekies (Alle alle). Auk 110:343-353

Kwasniewski S, Głuchowska M, Jakubas D, Wojczulanis-Jakubas K, Walkusz W, Karnovsky N, Błachowiak-Samolyk K, Cisek M, Stempniewicz L (2010) The impact of different hydrographic conditions and zooplankton communities on provisioning Little Auks along the West coast of Spitsbergen. Prog Oceangr. doi: 10.1016/j.pocean.2010.06.004

Lack D (1968) Ecological adaptations for breeding in birds. Methuen, London

Lovvorn JR, Liggins GA, Borstad MH, Calisal SM, Mikkelsen J (2001) Hydrodynamic drag of diving birds: effects of body size, body shape and feathers at steady speeds. J Exp Biol 204:1547-1557

Moe B, Stempniewicz L, Jakubas D, Angelier F, Chastel O, Dinesse F, Gabrielsen GW, Hanssen F, Karnovsky NJ, Rønning B, Welcker J, Wojczulanis-Jakubas K, Bech C (2009) Climate change and phenological responses of two seabird species breeding in the high-Arctic. Mar Ecol Prog Ser 393:235-246. doi: $10.3354 /$ meps08222

Nettleship DN, Evans PGH (1985) Distribution and status of the Atlantic Alcidae. In: Nettleship DN, Birkhead TR (eds) The Atlantic Alcidae. Academic Press, London, pp 53-154

Obrecht IIIHH, Pennycuick CJ, Fuller MR (1988) Wind tunnel experiments to assess the effect of back-mounted radio transmitters on bird body drag. J Exp Biol 135:265-273

Paredes R, Jones IL, Boness DJ (2005) Reduced parental care, compensatory behaviour and reproductive costs of thick-billed murres burdened with data loggers. Anim Behav 69:197-208. doi:10.1016/j.anbehav.2003.12.029

Philips RA, Xavier JC, Croxall JP (2003) Effects of satellite transmitters on albatrosses and petrels. Auk 120:1082-1090. doi: 10.1642/0004-8038(2003)120[1082:EOSTOA]2.0.CO;2

Ricklefts RE (1968) Weight recession in nestling birds. Auk 85:30-35

Ropert-Coudert Y, Knott N, Chiaradia A, Kato A (2007) How do different data logger sizes and attachment positions affect the diving behaviour of little penguins? Deep-Sea Res II 54:415-423. doi:10.1016/j.dsr2.2006.11.018

Saether BE, Andersen R, Pedersen HC (1993) Regulation of parental effort in a long-lived seabird: an experimental manipulation of the cost of reproduction in the antarctic petrel Thalassoica antarctica. Behav Ecol Sociobiol 33:147-150. doi:10.1007/ BF00216594

Saraux C, Le Bohec C, Durant J, Viblanc VA, Gauthier-Clerc M, Beaune D, Young-Hyang P, Yoccoz NG, Stenseth NC, Le Maho Y (2011) Reliability of flipper-banded penguins as indicators of climate change. Nature 469:203-206. doi:10.1038/nature09630

Schilling MF, Watkins AE, Watkins W (2002) Is Human Height Bimodal? The American Statistician 56(3):223-229. doi: 10.1198/00031300265

Sohle IS (2003) Effects of satellite telemetry on sooty shearwater, Puffinus griseus, adults and chicks. Emu 103:373-379. doi: 10.1071/MU03035

Stearns SC (1992) The evolution of life histories. Oxford University Press, New York
Steen H, Vogedes D, Broms F, Falk-Petersen S, Berge J (2007) Little auks (Alle alle) breeding in a High Arctic fjord system: bimodal foraging strategies as a response to poor food quality? Polar Res 26:118-125. doi:10.1111/j.1751-8369.2007.00022.x

Stempniewicz L (1980) Factors influencing the growth of the Little Auk, Plautus alle (L), nestlings on Spitsbergen. Ekol Pol 28:557-581

Stempniewicz L (1981) Breeding biology of the little auk Plautus alle in the Hornsund region, Spitsbergen. Acta Ornithol 18:1-26

Stempniewicz L (2001) Little auk Alle alle. J Birds Western Palearct 3:175-220

Stempniewicz L, Błachowiak-Samołyk K, Węsławski JM (2007) Impact of climate change on zooplankton communities, seabird populations and Arctic terrestrial ecosystem - a scenario. Deep Sea Res II 54:2934-2945. doi:10.1016/j.dsr2.2007.08.012

Taylor JRE, Konarzewski M (1989) On the importance of fat reserves for the little auk (Alle alle) chicks. Oecologia 81:551-558. doi: 10.1007/BF00378968

Taylor SS, Leonard ML (2001) Foraging trip duration for Humboldt Penguins tagged with recording devices. J Avian Biol 32:369-372

Tremblay Y, Cherel Y, Oremus M, Tveraa T, Chastel O (2003) Unconventional ventral attachment of time-depth recorders as a new method for investigating time budget and diving behavior of seabirds. J Exp Biol 206:1929-1940. doi:10.1242/jeb.00363

Velando A, Alonso-Alvarez C (2003) Differential body condition regulation by males and females in response to experimental manipulations of brood size and parental effort in the blue-footed booby. J Anim Ecol 72:846-856. doi:10.1046/j.1365-2656. 2003.00756.x

Weimerskirch H, Fradet G, Cherel Y (1999) Natural and experimental changes in chick provisioning in a long-lived seabird, the Antarctic Prion. J Avian Biol 30:165-174

Welcker J, Harding AMA, Karnovsky NJ, Steen H, Strøm H, Gabrielsen GW (2009a) Flexibility in the bimodal foraging strategy of a high Arctic alcid, the little auk Alle alle. J Avian Biol 40:388-399. doi:10.1111/j.1600-048X.2008.04620.x

Welcker J, Harding AMA, Kitaysky AS, Speakman JR, Gabrielsen GW (2009b) Daily energy expenditure increases in response to low nutritional stress in an Arctic-breeding seabird with no effect on mortality. Func Ecol 23:1081-1090. doi:10.1111/j.13652435.2009.01585.x

Wilson RP, Culik BM (1992) Packages on penguins and deviceinduced data. In: Priede IG, Swift SM (eds) Wildlife telemetry: remote monitoring and tracking of animals. Ellis Horwood, Chichester

Wilson RP, Grant WS, Duffy DC (1986) Recording devices on freeranging marine animals: does measurement affect foraging performance? Ecology 67:1091-1093. doi:10.2307/1939832

Wojczulanis K, Jakubas D, Walkusz W, Wenneberg L (2006) Differences in food quantity and quality delivered to chick by male and female of the monogamous Little Auk Alle alle during the chick rearing period. J Ornithol 147:543-548. doi:10.1007/ s10336-006-0077-1

Wojczulanis-Jakubas K, Jakubas D, Karnovsky NJ, Walkusz W (2010) Foraging strategy of little auks under divergent conditions on feeding ground. Polar Res 29:22-29. doi:10.1111/j.17518369.2009.00145.x

Wojczulanis-Jakubas K, Jakubas D, Kidawa D, Słonina A (2011) Is the transition from biparental to male-only care in a monogamous seabird related to changes in body mass and stress level? J Ornithol. (in press)

Zach R (1988) Growth-curve analysis: a critical reevaluation. Auk 105:208-210 